\title{
Virtual Screening of Some Antivirals That Can Be Repurposed As Potential Effective Drugs against SARS-CoV-2
}

Mohammad Rejaur Rahman ${ }^{1 *}$, Anik Banik ${ }^{3}$, Ishtiak Malique Chowdhury ${ }^{2}$, Emran Hossain Sajib $^{3}$ and Sanchita Sarkar ${ }^{3}$

1 Assistant Professor, Department of Molecular Biology \& Genetic Engineering, 2 MS student, Department of Molecular Biology \& Genetic Engineering, 3 Faculty of Biotechnology \& Genetic Engineering, Sylhet Agricultural University (SAU), Sylhet-3100, Bangladesh.

\section{Abstract}

SARS-CoV-2 has triggered a big epidemic among people around the world and it is the newest in the sequence to be prevalent among other infectious diseases. Drug repurposing concept has been utilized effectively for numerous viral infections. Considering the situation and the urgency, the idea of drug repurposing for coronavirus infection (COVID-19) is also being studied. Screening with molecular docking method for 29 antiviral drugs was performed against SARSCoV-2 primary protease proteins (MPP), spike ecto-domain, spike receptor binding domain, Nsp9 RNA binding protein, and HR2 domain. Among these drugs, Indinavir, Sorivudine, Cidofovir and Darunavir show minimum docking scores with all key proteins in terms of least binding energy. For ADME (Absorption, Distribution, Metabolism, and Excretion) analysis, the top 4 drug candidates were further used to examine their drug profiles for suitability against SARS-CoV-2. The toxicity testing of top drug candidates showed no significant carcinogenic, mutagenic or skin irritating impacts. Indinavir may possess some complexity to heart. In addition, the drug similarity prediction revealed several approved structural analogues such as Telbivudine, Tenofovir, Amprenavir, Fosamprenavir etc which also could be used to treat viral infections. The study may speed up the findings of therapeutics against SARS-CoV-2.

Keywords: SARS-CoV-2, Covid-19, Molecular Docking, Drug Repurposing, Antivirals.

*Corresponding author

Mohammad Rejaur Rahman, Department of Molecular Biology \& Genetic Engineering, Sylhet Agricultural University, Sylhet-3100, Bangladesh. E-mail: rejaur.mge@ sau.ac.bd 


\section{Introduction}

On December 31, 2019, the Health Authority of China notified the World Health Organization (WHO) of multiple cases of pneumonia in Wuhan City of Hubei Province in central China [1, 2]. This emerging infectious disease was later referred to as coronavirus disease 2019 (COVID-19) and the causative agent was identified as severe acute respiratory syndrome coronavirus 2 (SARS-CoV-2) [3]. The most renowned Severe Acute Respiratory Syndrome (SARS) scientist, Dr. Zhengli Shi, suggested the bats as the sources of SARS-CoV-2 [4] and other Chinese researchers have claimed that Middle East Respiratory Syndrome (MERS) and (SARS) including coronaviruses are likely to originate from bats in China $[5,6]$. This SARS-CoV-2 is a singlestranded, enveloped, positive-sense RNA (+ ssRNA) virus[7]. It belongs to Betacoronavirus such as SARS -CoV and MERS-CoV and shares genetic similarities with them about $79 \%$ and about $50 \%$ respectively [8]. Because of human-to - human transmission through respiratory droplets the virus has become so deadly, particularly when people are in close contact (within 1-2 m) [9, 10, 11]. The COVID-19 disease may be symptomatic, presymptomatic, and asymptomatic [12]. Respiratory symptoms frequently reported include fever, dry cough, dyspnoea, chest pain, fatigue and myalgia, headache, dizziness, stomach pain, diarrhea, nausea, and vomiting are the less common symptoms $[13,14]$. The epidemic spread across the world so quickly and widely after emergence that on March 11, 2020, WHO declared the curse as a global pandemic.

The pandemic stymied the strong health sectors of leading countries such as China, the UK, the United States, Russia, Germany, Canada, Italy, Spain, France and others. As of 2 July 10,694,288 people were infected and COVID-19 caused 516,210 deaths worldwide [15]. Researchers from different countries are making every attempt to develop new vaccines and antiillness medications. Numerous laboratories around the world, as well as research and pharmaceutical companies, are developing new medicines and vaccines $[16,17]$. However, it is required nearly one year before drugs and/or vaccines to be available for administration to patients, as it is incredibly time consuming process. In that case, repurposing current medications may play a major role in reducing symptoms or curing the disorder. Some medications such as antimalarial drugs ( e.g. chloroquine, hydroxychloroquine) or anti-HIV drugs (e.g. lopinavir, ritonavir, saquinavir) have shown substantial positive results against COVID-19 in many countries $[18,19,20]$. 
Drug repurposing, also known as repositioning, is an important approach to the speedy identification of therapeutic drugs with a proven safety profile to fight novel infectious diseases $[21,22,23]$. This repurposing strategy has been effective in identifying potential drug candidates against many diseases such as Ebola disease, hepatitis $\mathrm{C}$ virus and infection with the zika virus [24, 25, 26, 27]. Moreover, in-silico based screening has become a highly significant tool to mitigate the drawbacks of antiviral drug discovery. Screening of drugs by computational methods via docking approach saves expenditure as well as time [28, 29, 30,31, 32]. Besides, existing drugs approved for some diseases are safe for human consumption [22], and only their efficacy against the targeted disease needs to be proved [33]. So, in silico drugs repurposing strategy can be a great approach in which SARS-CoV-2 significant proteins, such as proteins required for viral replication or binding to human receptor (ACE2: angiotensin-converting enzyme 2), will be targeted.

Our present research focused on virtual screening and protein-ligand docking of a variety of Food and Drug Administration (FDA) - approved antiviral drugs against the promising target drug SARS-CoV-2 main protease (Mpro, PDB ID-6W63), very necessary for viral replication, and spike receptor binding domain (PDB ID-6MOJ), needed to bind to human receptor ACE2.Other drug targets include Nsp9 (Non structural protein-9) RNA binding protein, Spike Ecto domain and HR2 domain which involve in viral replication by binding with single stranded RNA, receptor binding as well as fusion and virus-cell membrane fusion respectively. Here, screened FDA approved antiviral drugs, such as Sorivudine, Tipranavir, Zalcitabine, Zidovudine, Indinavir, Nelfinavir, Nevirapine etc. are applied against human immunodeficiency virus (HIV). Other drugs like Trifluridine, Valganciclovir, Vidarabine, Pritelivir etc. are used for human herpes virus disease. Besides, we also tested drugs that are effective against Influenza A and Influenza B Virus, Hepatitis B and Hepatitis C virus, Respiratory Syncytial Virus (RSV) and other RNA/DNA viruses to detect their effectiveness against the selected drug targets of SARSCoV-2. 


\section{Materials and Methods}

\subsection{Retrieval of SARS-CoV-2 proteins/protein-domains and antiviral drugs}

The RCSB Protein Data Bank [34] was used for the retrieval of 3D structures of SARS-CoV-2 main protease (PDB ID: 6W63), Nsp9 (Non-structural protein-9) RNA binding protein (PDB ID: 6W4B), Spike receptor binding domain (PDB ID: 6M0J), spike ecto-domain (PDB ID : 6VYB), and HR2 Domain (PDB ID : 6LVN). A total of 29 antiviral drugs, used against different virus (e.g. HIV, HSV etc.), were extracted from PubChem database (https://pubchem.ncbi.nlm.nih.gov/) [35] in SDS (3D) format (Supplementary file 1). These drugs were also crosschecked in DrugBank database (https://www.drugbank.ca/) [36] (Supplementary file 2). Then the retrieved SDS structures were converted into PDB format by OpenBabel v2.3 software for further analysis [37].

\subsection{Molecular docking of antiviral drugs against SARS-CoV-2 proteins/protein-domains}

Molecular docking is a necessary tool in drug discovery that simplify the way of screening out the appropriate therapeutics against specific drug targets of infectious pathogens [38]. This effective approach provides rankings of docked compounds according to the binding affinity of ligand-receptor complexes $[39,40]$. PatchDock server was used to measure the binding affinity of 29 antiviral drugs with different SARS-CoV-2 protein / prorein domains (drug targets / macromolecules) [41, 42]. To refine the docked complexes, FireDock refinement tool [43] was employed. An experimental study claimed alpha-ketoamide (CID 6482451) as a primary protease inhibitor for SARS-CoV-2 [44]. Thus, it was docked against all five macromolecules being used as positive control in this study. Finally, the ligand-receptor complexes were visualized by Discovery Studio v3.1 [45] and PyMOL v2.0 [46].

\subsection{Analyzing drug profiles of active antiviral drugs}

A standard drug candidate should have appropriate absorption, distribution, metabolism, excretion, and toxicity (ADMET) properties along with adequate effectiveness against the therapeutic target [47]. These parameters greatly regulate the pharmacological activity and performance of a drug [48]. Among these, the properties of absorption, distribution, metabolism and excretion ( ADME) were assessed using SwissADME server [49]. BOILED-Egg model was 
used to assess the Blood-brain barrier (BBB) in the studied drugs [50]. After that, pkCSM [51], an online tool, was utilized to predict the relative toxicity of top drugs. It is an effective approach to predict pharmacokinetic properties depending on graph-based signatures that represent distance patterns between atoms [51]. Besides, carcinogenicity of selected top drugs was analysed using admetSAR [52].

\subsection{Prediction of drug targets and available drug molecules from DrugBank}

Screening of top drugs was performed to find similar potential drugs that can be used against SARS- CoV-2. To predict the probable macromolecular targets of top drugs, SwissTargetPrediction was utilized [53]. The server estimates on about 3000 proteins according to a mix of 2D and 3D uniformity with a library of 370000 recognized bioactive compounds. Furthermore, SwissSimilarity web tool was used to find out the potential drug molecules against SARS-CoV-2 by homology screening of predicted top drugs [54]. The server uses several strategies, such as FP2 fingerprints, electroshape, spectrophores and align-IT to predict experimental, approved or commercially available drugs from DrugBank via virtual screening of numerous libraries of small molecules [54].

\section{Results}

\subsection{Molecular docking of antiviral drugs against SARS-CoV-2 proteins/protein-domains}

The retrieved structures of five SARS-CoV-2 proteins/protein-domains (macromolecules) and antiviral drugs (ligands) were optimized and executed for molecular docking to compute the binding affinity between selected macromolecules and ligands. According to binding energy the antiviral drugs were ranked and the drugs which showed minimum binding energy were selected as top scorers (Supplementary File 3). In this way, four top scorers, Indinavir, SorivudineCidofovir and Darunavir, were chosen for further analysis (Table 1, Figure1). Sorivudine, Darunavir and Cidofovir showed highest binding affinity with spike receptor binding domain $(-52.99 \mathrm{kcal} / \mathrm{mol})$, spike ecto-domain $(-68.01 \mathrm{kcal} / \mathrm{mol})$ and Nsp9 RNA binding protein $(-52.74 \mathrm{kcal} / \mathrm{mol})$ respectively, while Indinavir showed best binding affinity with both HR2 Domain $(-37.42 \mathrm{kcal} / \mathrm{mol})$ and main protease $(-69.23 \mathrm{kcal} / \mathrm{mol})$ (Table 1 and Figure 2 and 3). Besides, Sorivudine also experienced excellent binding interactions with spike ecto-domain ($52.28 \mathrm{kcal} / \mathrm{mol})$ and main protease $(-59.62 \mathrm{kcal} / \mathrm{mol})$, while Darunavir showed considerable 
interactions with spike receptor binding domain (-46.88 kcal/mol), Nsp9 RNA binding protein ($47.62 \mathrm{kcal} / \mathrm{mol})$ and main protease $(-55.06 \mathrm{kcal} / \mathrm{mol})$ as well.

\subsection{ADME analysis of selected top drugs}

To evaluate drug profiles of top antiviral drugs, various ADME properties, such as physicochemical parameters, pharmacokinetics, lipophilicity, water solubility, medicinal chemistry of top drugs were assessed (Table 2, Figure 4). Indinavir showed higher GI absorption, while lower for Sorivudine, Cidofovir and Darunavir. BOILED-Egg model that counted bloodbrain barrier $(\mathrm{BBB})$ revealed no $\mathrm{BBB}$ permeant within the studied top drugs. Inhibition effects analysis with different CYP isoforms (CYP1A2, CYP2D6, CYP2C9, CYP2C19, CYP3A4) expressed that these top drugs had no interaction probability with cytochromes P450 isoforms, except Indinavir with CYP2D6 and Darunavir with CYP3A4. All of the five drugs were water soluble from poor to high level, while Cidofovir showed maximum solubility. Furthermore, these five drugs showed zero alert for pain (Table 2).

\subsection{Analysis of Toxicity pattern of top drugs}

Different toxicity parameters such as AMES toxicity, Oral Rat toxicity, skin sensitization, T. pyriformis toxicity, minnow toxicity, hepatotoxicity etc. were analysed (Table 3). Result revealed negative outcomes in AMES test for all drugs which indicating the drugs as nonmutagenic. According to the result, all of the drugs acted as hERG I and hERG II inhibitors, except Indinavir which showed positive outcome againsthERG II. Besides, they showed negative results for skin sensitization, and oral rat acute toxicity, LD50, values ranged from 1.74 to $2.107 \mathrm{~mol} / \mathrm{kg}$ for these top drugs. Minnow Toxicity values of all drugs were more than $-0.3 \log$ $\mathrm{mM}$ proving them non- toxic. Besides, admetSARpredictedcarcinogenicity for these drugs was negative, declaring them as non carcinogen. However, positive hepatotoxicity results of all drugs indicating the possibility for association with the disruption of normal function of liver.

\subsection{Prediction of drug targets and available drug molecules from DrugBank}

Prediction of effective drug targets against the top drugs revealed some other similar drugs that may be potential against SARS CoV2. Maximum targets belong to protease, transferese and enzyme class. Other target class includes electrochemical transporter, cytochrome p450, family a 
g protein-coupled receptor, phosphodiesterase, oxidoreductase, transferasedna polymerase alpha subuni,transferaseetc(Table 4, Figure 5). To predict structural similar bioactive small compounds against SARS-CoV-2 from DrugBank, a ligand-based screening strategy was employed (Table 5). Quinapril (DB00881) and Sirolimus (DB00877), two approved drugs along with an experimental drug, L-756,423 (DB02009), were found as analogous withIndinavir with score of $0.048,0.014$ and 0.906 respectively. Sorivudinpredicted two similar approved drugs Telbivudine (DB01265) and Idoxuridine (DB00249), while Cidofovir predicted Tenofovir (DB00300) and Riboflavin (DB00140) as similar approved drugs. Besides, Darunavir also predicted two similar approved drugs, Amprenavir (DB00701) and Fosamprenavir (DB01319). These results of similarity suggest the efficacy of these related drugs against SARS-CoV-2 and indicate further experimental studies.

\section{Discussion}

SARS-CoV-2 belongs to a group of viruses that can contaminate humans as well as vertebrate animals. There is no recorded or approved potent drug or vaccine for treating the patient infected with SARS-CoV-2. There are a few candidates within the investigational stages but many of them raised controversy issues $[4,55]$. In this study, attempts were taken to screen and suggest to repurpose some FDA approved antiviral drugs as an inhibitory agent of SARS-CoV-2 using molecular docking strategy.The study suggested that Indinavir, Sorivudine,Cidofovir and Darunaviralong with their top derivatives, may be effective against SARS-CoV-2.

Drug repurposingis one of the exciting applications of computational pharmacology for finding new uses for existing drugs. Computer-based analysis can speed up the identification of drug targets, screening and refinement of drug candidates. It too facilitatecharacterization of side effects and foresee drug resistance pattern. Antiviral drugs such as Ledipasvir, Elbasvir, Nelfinavir, Danoprevir, Darunavir, lopinavir and ritonavir were previously used as an inhibiting agent for HCV and HIV [56]. Lopinavir, Ritonavir and Nelfinavir have been reported as potential drug candidates in few earlier studies using repurposing strategythat target Mpro of SARS-CoV-2 [57]. Besides, a recent study emphasizedon alpha-ketoamide as a Mproinhibitor of this virus to determine it's efficacy to become a drug candidate [44]. Main protease proteins (Mpro) or RNA-dependent RNA polymerase of SARS-CoV-2 were used as probable drug targets in almost all previous experiments. In this study, we assess the potency of 29 FDA approved 
commercially available antiviral drugs against SARS-Cov-2 main protease (6W63), spike ectodomain (6VYB), spike receptor binding domain (6M0J),Nsp9(Non-structural protein-9) RNA binding protein $(6 \mathrm{~W} 4 \mathrm{~B})$, and $\mathrm{HR} 2$ domain $(6 \mathrm{LVN})$ using molecular docking approach [58].SARS-CoV-2 Mpro is an appealing pharmacological target for the design of drugs against covid-19 as the Mpro polyprotein cleavage facilitates the formation of thehelicase and theRNAdependent RNA polymerase ( $\mathrm{RdRp})$ which are the prerequisite proteins for viral replication initiation $[59,60]$. In addition, human proteases have no similar cleavage specificity to that of coronavirus proteases so inhibitors of these proteins are safe [44].ORF1a encoded Nsp9 RNA binding protein which is involved in the synthesis of viral RNA. Nsp9 has evolved, possibly, from a protease and it's a dimeric protein. Nsp9 communicates with nsp8, actions that may be crucial to its function. Viral replication complexes are also connected with membranes and in this case, nsp9 aids.Nsp9 may likely have an RNA binding activity as a putative component in the Replication complex. In this way it makes a difference in viral replication by binding with single stranded RNA.SARS-Cov-2 moreover have a surface structural spike glycoprotein (S) which plays crucial role in association with the have cell receptor and subsequent virus passage into the cell. The S protein has two subunits, the S1 (receptor-binding) and the S2 (membrane fusion) domains40. The attachment of the receptor-binding subunit to the receptor enables interaction between the HR1 and HR2 domains in the membrane fusion subunit and forms a sixhelix bundle and this conformational change results in a close apposition of the fusion peptide leading to virus-cell membrane fusion [61]. Thus, spike protein binds to human ACE2 and CLEC4M/DC-SIGNR receptors and internalization of the virus into the endosomes of the host cell induces conformational changes in the S glycoprotein [62]. So, all those macromolecules are potential target for repurposing study.

Docking result revealed that four drug molecules i.e. Indinavir, Sorivudine,Cidofovir and Darunavir scored high for each five macromolecules and bound with lowest global energy (Table 1).Indinavir had highest binding binding affinity with SARS-CoV-2 main protease (-69.23 $\mathrm{kcal} / \mathrm{mol})$ and HR2 Domain $(-37.42 \mathrm{kcal} / \mathrm{mol})$. The rest of three drug candidate i.e. Sorivudine,Cidofovir and Darunavir had highest binding affinity with Spike receptor binding domain (-52.99 kcal/mol), Nsp9 RNA binding protein $(-52.74 \mathrm{kcal} / \mathrm{mol})$ and Spike ecto-domain($68.01 \mathrm{kcal} / \mathrm{mol}$ )repectively. Indinavir, an alpha-amino acid amide protease inhibitor used to treat Human immunodeficiency virus (HIV) infection. Indinavir inhibits the activity of the enzyme by 
binding to the protease active site. This inhibition facilitates the formation of immature noninfectious viral particles through preventing cleavage of the viral polyproteins [63].Sorivudine, an antimetabolite and synthetic analogue of thymidine. Thymidine kinase activity in the bodyphosphorylatedsorivudineand is absorbed into the viral DNA instead of the correct nucleoside [64].So the viral DNA cannot be replicated and the virus cannot grow because sorivudine is a competitive inhibitor of DNA polymerase.Cidofovir, a nucleotide analogue and is active against herpes cytomegalovirus (CMV) retinitis infection and chronic hepatitis $\mathrm{B}$ which acts through the selective inhibition of viral DNA polymerase. As a result Cidofovir reduce synthesis of viral DNA (10).Darunavir, a non-peptide protease inhibitor,with a distinct chemical structure that enhanced binding affinity of the drug [65]. This antiviral prevents HIV replication by binding to the enzyme, stopping the catalytic activity and dimerization of HIV-1 protease. Specifically, it inhibits the cleavage of HIV encoded Gag-Pol proteins [66] in cells that have been infected with the virus, halting the formation of mature virus particles, which spread the infection.

ADME data is crucial in drug development project whether it is determined by in vitro, in vivo or computational approaches because many drug development project failed during clinical trials due to poor ADME data [67]. Computational analysis of ADME profile of drug candidates is very fast and cost effective compare to other methods. In silico ADME analysis of top four drug candidates did not show any undesirable consequences that could reduce their drug likeliness properties. All of the drug candidates are water soluble and absorbable in GI where cidofovir is highly soluble in water and indinavir has high absorption rate in GI.However, these four drugs are non-permeate to BBB and it would not create any problem as SARS-CoV-2 is a respiratory disease. Most of the target class for the top drug candidates belonged to the categories of enzymes (e.g. Electrochemical transporter, Protease, Transferase, Family A G protein-coupled receptoretc(Table 4). The toxicity pattern of drug molecule is related to their structure. In Europe and the United States structure-activity relationships (SARs) have been widely used to predict toxicity by various bioinformatics tools [68]. The toxicity prediction results of our study showed that all four drug candidates are non-carcinogenic, non-mutagenic and insensitive to skin but these showed hepatotoxicity. Except Indinavir, all the drug candidates are friendly to heart as they showed negative result in hERGI \&hERG II inhibitors prediction test. Overall the toxicity prediction test suggested those drugs are safe to take as a medication to treat Covid-19. 
Ligand based drug similarity analysis identified three structural analogs of Indinavir where two (Quinapril, Sirolimus) are approved and another one (L-756,423) is in experimental stage. Quinapril is an ACE (angiotensin converting enzyme) inhibitors and used to treat hypertension and heart failure [69]. As we previously know that SARS-CoV-2 entry into the host cell by interacting with ACE receptor, so this analog could be a drug of choice to treat Covid-19. Drug similarity analysis revealed two (Telbivudine\&Idoxuridine) approved analog for Sorivudine and both of them act similarly by incorporating into viral DNA in place of thymidine and terminate replication process. Telbivudine\&Idoxuridine used to treathepatitis B virus (HBV) and Herpes simplex virus respectively [70, 71]. Amprenavir and Fosamprenavir are two approved analog of Darunavir and both of them are protease inhibitors. These analogs prevent the processing of viral Gag and Gag-Pol polyprotein and produce noninfectious, immature viral particles that is harmless to host cell $[72,73]$. The results encourage that all thesecompounds could be used as potential drug candidates against SARS-CoV-2.

\section{Conclusion}

The results suggest that Indinavir, Sorivudine, Cidofovir and Darunavir could be options to end up the SARS-CoV-2 era. Furthermore, several biologically active structural analogs from DrugBank i.e. Telbivudine, Tenofovir, Fosamprenavir, Tenofoviretcmay also be effective and show potency against the viral pathogen. Due to encouraging result we highly recommened these drug candidates as a poteintial fighter and refers in vivo trials for the experimental validation of our findings against notorious deadly SARS-CoV-2 virus.

\section{References}

[1] N.Zhu, D.Zhang, W. Wang,X. Li, B. Yang, J.Song,X.Zhao,B.Huang,W.Shi,R. Lu,andP.Niu, A novel coronavirus from patients with pneumonia in China, 2019, The New England Journal of Medicine 382 (2020) 727-733. doi: 10.1056/NEJMoa2001017.

[2] C.I. Paules, H.D. Marston and A.S.Fauci, Coronavirus infections-more than just the common cold, The Journal of the American Medical Association 323 (8) (2020) 707-708. doi:10.1001/jama.2020.0757.

[3] C.C. Lai, T.P. Shih, W.C. Ko, H.J.Tang, and P.R. Hsueh, Severe acute respiratory syndrome coronavirus 2 (SARS-CoV-2) and corona virus disease-2019 (COVID-19): the 
epidemic and the challenges, International Journal of Antimicrobial Agents 55 (2020)105924.doi:10.1016/j.jantimicag.2020.105924.

[4] P. Zhou, X.L.Yang, X.G.Wang, B. Hu, L. Zhang, W. Zhang,H.R. Si, Y.Zhu et al.,A pneumonia outbreak associated with a new coronavirus of probable bat origin, Nature579(2020)270-273. doi: 10.1038/s41586-020-2012-7.

[5] S.Xia,Q.Lan,J.Pu,C.Wang, Z.Liu, W.Xu, Q.Wang, H.Liu, S.Jiang, L.Lu, Potent MERSCoV Fusion Inhibitory Peptides Identified from HR2 Domain in Spike Protein of Bat Coronavirus HKU4, Viruses 11 (2019) 56. doi: 10.3390/v11010056.

[6] Y.Yuan, J.Qi,R.Peng, C.Li, G.Lu, J.Yan,Q.Wang,G.F. Gao, Molecular Basis of Binding between Middle East Respiratory Syndrome Coronavirus and CD26 from Seven Bat Species, Journal of Virology 94 (2020) e01387.doi:10.1128/JVI.01387-19.

[7] C.Wu, Y. Liu, Y.Yang, P. Zhang, W. Zhong, Y.Wang et al., Analysis of therapeutic targets for SARS-CoV-2 and discovery of potential drugs by computational methods, Acta Pharm Sin B 10 (2020) 766-788. doi: 10.1016/j.apsb.2020.02.008.

[8] R.Lu, X.Zhao, J.Li et al., Genomic characterisation and epidemiology of 2019 novel coronavirus: implications for virus origins and receptor binding, The Lancet 395 (2020) 1033-1034. doi: 10.1016/S0140-6736(20)30251-8.

[9] CDC, 2020c. Coronavirus Disease 2019 (COVID-19)—Transmission. Centers for Disease Control and Prevention (CDC), United States.

[10] CDC, 2020h. HowCOVID-19 Spreads. Centers for Disease Control and Prevention (CDC), U.S.

[11] WHO, 2020q. Q\&a on Coronaviruses. World Health Organization (WHO).

[12] WHO, 2020c. Coronavirus Disease (COVID-2019) Situation Report-73. World Health Organization (WHO).

[13] C.Huang, Y.Wang, X. Li, L.Ren, J.Zhao, Y.Hu et al., Clinical features of patientsinfected with 2019 novel coronavirus in Wuhan, China, The Lancet 395 (2020) 497-506. doi:10.1016/S0140-6736(20)30183-5.

[14] D.Wang, B.Hu, C.Hu, F.Zhu, X.Liu, J.Zhang et al., Clinical characteristics of 138 hospitalized patients with 2019 novel coronavirus-infected pneumonia in Wuhan, China, The Journal of the American Medical Association 323(11) (2020) 1061-1069. doi:10.1001/jama.2020.1585. 
[15] "COVID-19 Dashboard by the Center for Systems Science and Engineering (CSSE) at Johns Hopkins University (JHU)". ArcGIS. Johns Hopkins University. Retrieved 2 July 2020.

[16] C.V. Herst, S.Burkholz, J.Sidney, A. Sette, P.Harris, S.Massey, T.Brasel, E.CunhaNeto,D.Rosa, W.Chao, et al., An Effective CTL Peptide Vaccine for Ebola Zaire Based on Survivors' CD8+ Targeting of a Particular Nucleocapsid Protein Epitope with Potential Implications for COVID-19 Vaccine Design, Vaccine 38 (2020) 4464-4475. doi:10.1016/j.vaccine.2020.04.034.

[17] G.Yamey, M.Schäferhoff, R.Hatchett, M.Pate, F. Zhao, K.K. McDade, Ensuring global access to COVID-19 vaccines, The Lancet 395 (2020) 1405-1406. doi:10.1016/S01406736(20)30763-7.

[18] J. Gao, Z.Tian, X.Yang, Breakthrough: Chloroquine phosphate has shown apparent efficacy in treatment of COVID-19 associated pneumonia in clinical studies, BioScience Trends 14 (2020) 72-73. doi: 10.5582/bst.2020.01047.

[19] P.Gautret, J.C.Lagier, P.Parola, V.T. Hoang, L.Meddeb, M.Mailhe,B.Doudier, J. Courjon, V.Giordanengo,V.E. Vieira et al., Hydroxychloroquine and azithromycin as a treatment of COVID-19: Results of an open-label non-randomized clinical trial, International Journal of Antimicrobial Agents $56 \quad$ (2020) 105949. doi:10.1016/j.ijantimicag.2020.105949.

[20] J.Stebbing, A.Phelan, I.Griffin, C.Tucker, O. Oechsle, D.Smith, P. Richardson, COVID19: Combining antiviral and anti-inflammatory treatments, The Lancet Infectious Disease 20 (2020) 400-402. doi:10.1016/S1473-3099(20)30132-8.

[21] T. T. AshburnandK. B. Thor, Drug repositioning: identifying and developing new uses for existing drugs, Nature Reviews Drug Discovery 3 (2004) 673-683. doi: $10.1038 / \mathrm{nrd} 1468$.

[22] 22.J. Li, S.Zheng, B.Chen, A. J. Butte, S. J. Swamidass, andZ.Lu, A survey of current trends in computational drug repositioning, Briefings in Bioinformatics 17 (2016) 2-12. doi: 10.1093/bib/bbv020.

[23] G.Chopra, and R.Samudrala, Exploring Polypharmacology in Drug Discovery andRepurposing Using the CANDO Platform, Current Pharmaceutical Design 22 (2016) 3109- 3123. doi:10.2174/1381612822666160325121943. 
[24] J.Kouznetsova,W. Sun, C.Martinez-Romero, G.Tawa,P. Shinn,C.Z. Chen,A.Schimmer, P. Sanderson, J.C.McKew, W.Zheng and A.Garcia-Sastre, Identification of 53 compounds thatblock Ebola virus-like particle entry via a repurposing screen of approved drugs, Emerging Microbes \& Infections 3 (2014) 1-7. doi:10.1038/emi.2014.88.

[25] L. M. Johansen, L. E. DeWald, C. J. Shoemaker, B. G. Hoffstrom, C. M. Lear-Rooney, A. Stossel, E. Nelson, S. E.Delos, J. A. Simmons, J. M. Grenier, and L. T.Pierce, A screen of approved drugs and molecular probes identifies therapeutics with anti-Ebola virus activity, Science Translational Medicine 7 (2015) 290ra89. doi: 10.1126/scitranslmed.aaa5597.

[26] S. He, B.Lin,V.Chu,Z.Hu,X.Hu, J.Xiao, A.Q.Wang, C.J.Schweitzer, Q.Li, M.Imamura and N.Hiraga, Repurposing of the antihistamine chlorcyclizine and related compounds for treatment of hepatitis C virus infection, Science Translational Medicine 7 (2015) 282ra49. doi: 10.1126/scitranslmed.3010286.

[27] N.J.Barrows, R. K. Campos, S.T.Powell, K. R.Prasanth, G.Schott-Lerner, R.SotoAcosta, G. Galarza-Munoz, E. L.McGrath, R.Urrabaz-Garza, J. Gaoand P. Wu, A screen of FDA-approved drugs for inhibitors of Zika virus infection, Cell Host \& Microbe 20 (2016) 259-270. doi: 10.1016/j.chom.2016.07.004.

[28] G. Jones, P. Willett, R. C.Glen, A. R. Leach and R.Taylor, Development and validationof a genetic algorithm for flexible docking, Journal of molecular biology 267 (1997) 727748. doi: 10.1006/jmbi.1996.0897.

[29] R. A. Friesner, et al., Glide: a new approach for rapid, accurate docking and scoring. 1. Method and assessment of docking accuracy, Journal of Medicinal Chemistry 47(2004) 1739- 1749. doi:10.1021/jm0306430.

[30] J. J. Irwin and B. K. Shoichet, Docking Screens for Novel Ligands Conferring New Biology, Journal of Medicinal Chemistry 59 (2016) 4103-4120. doi:10.1021/acs.jmedchem.5b02008.

[31] N.Mohanasundaram and T.Sekhar, Computational Studies of Molecular Targets Regarding the Adverse Effects of Isoniazid Drug for Tuberculosis, Current Pharmacogenomics and Personalized Medicine 16(2018) 210218.doi:10.2174/1875692116666181108145230. 
[32] M. S.Murgueitio, M.Bermudez, J.Mortier, G.Wolber,Insilico virtual screening approaches for anti-viral drug discovery, Drug Discovery Today: Technologies 9 (2012) e219-e225. doi: 10.1016/j.ddtec.2012.07.009.

[33] M.R.Hurle, L. Yang, Q.Xie, D. K. Rajpal, P. Sanseau and P. Agarwal, Computational drug repositioning: from data to therapeutics, Clinical Pharmacology \& Therapeutics 93 (2013) 335-341. doi: 10.1038/clpt.2013.1.

[34] P. W.Rose, A.Prlić, A.Altunkaya, C.Bi, A. R.Bradley, C. H.Christie et al., The RCSB protein data bank: Integrative view of protein, gene and 3D structural information, Nucleic Acids Research 45 (2017) D271-D81. doi: 10.1093/nar/gkw1000.

[35] S.Kim, P. A.Thiessen, E. E.Bolton, J.Chen, G.Fu, A.Gindulyte, L.Han, J.He, S.He, B. A.Shoemaker, J.Wang, PubChem substance and compound databases, Nucleic Acids Research 44 (2016) D1202-D13. doi: 10.1093/nar/gkv951.

[36] D. S.Wishart, Y. D.Feunang, A. C.Guo, E. J.Lo, A.Marcu, J. R. Grant and N.Assempour, DrugBank 5.0: a major update to the DrugBank database for 2018, Nucleic Acids Research 46 (2018) D1074-D1082. doi: 10.1093/nar/gkx1037.

[37] N. M.O'Boyle, M.Banck, C.A.James, C.Morley, T.Vandermeersch, G. R.Hutchison, Open Babel: An open chemical toolbox, Journal of cheminformatics 3 (2011) 33. doi: 10.1186/1758-2946-3-33.

[38] X. Y.Meng, H. X.Zhang, M.Mezei, M.Cui, Molecular docking: a powerful approach for structure-based drug discovery, Current Computer-Aided Drug Design 7 (2011) 146-57. doi: 10.2174/157340911795677602.

[39] S.Y.Huang, X.Zou, Advances and challenges in protein-ligand docking, International Journal of Molecular Sciences 11 (2010) 3016-3034. doi: 10.3390/ijms 11083016.

[40] F.López-Vallejo, T.Caulfield,K.Martínez-Mayorga, M.A.Giulianotti, R. A. Houghten, A.Nefzi, J.L. Medina-Franco, Integrating virtual screening and combinatorial chemistry for accelerated drug discovery, Combinatorial Chemistry \& High Throughput Screening 14 (2011) 475-487. doi: $10.2174 / 138620711795767866$. 
[41] D. Schneidman-Duhovny, Y.Inbar, R.Nussinov, H.J.Wolfson, PatchDock and SymmDock: servers for rigid and symmetric docking, Nucleic Acids Research 33 (2005) W363-W367. doi: 10.1093/nar/gki481.

[42] K.F.Azim, S.R. Ahmed, A.Banik, M.M.R. Khan, A. Deb and S.R.Somana, Screening and druggability analysis of some plant metabolites against SARSCoV-2: An integrative computational approach, Informatics in Medicine Unlocked 20 (2020) 100367. doi: 10.1016/j.imu.2020.100367.

[43] E. Mashiach, D.Schneidman-Duhovny, N.Andrusier, R.Nussinov, H. J.Wolfson, FireDock: a web server for fast interaction refinement in molecular docking, Nucleic Acids Research 36 (2008) W229-W232. doi: 10.1093/nar/gkn186.

[44] L.Zhang, D.Lin, X.Sun, U Curth, C.Drosten, L.Sauerhering, S.Becker, K.Rox, R.Hilgenfeld, Crystal structure of SARS-CoV-2 main protease provides a basis for design of improved $\alpha$-ketoamide inhibitors, Science 368 (2020) 409-412. doi: 10.1126/science.abb3405.

[45] Q.Wang, J.He, D.Wu, J.Wang, J.Yan, H.Li, Interaction of $\alpha$-cyperone with human serum albumin: Determination of the binding site by using Discovery Studio and via spectroscopic methods, Journal of Luminescence 164 (2015) 81-85. doi: 10.1016/j.jlumin.2015.03.025.

[46] W.L. DeLano, Pymol: An open-source molecular graphics tool, CCP4 Newsletter on protein crystallography, 40(1) (2002) 82-92.

[47] L. Guan, H.Yang, Y.Cai et al., ADMET-score - a comprehensive scoring function for evaluation of chemical drug-likeness, MedChemComm 10 (1) (2018) 148-157. doi:10.1039/c8md00472b.

[48] S. K. Balani, V.S.Devishree, G. T. Miwa, L. S. Gan, J. T. Wu, F.W. Lee, "Strategy of utilizing in vitro and in vivo ADME tools for lead optimization and drug candidate selection", Current Topics in Medicinal Chemistry 5 (2005) 1033-8. doi: 10.2174/156802605774297038.

[49] A.Daina, O. Michielin, V. Zoete, SwissADME: A free web tool to evaluate pharmacokinetics, drug-likeness and medicinal chemistry friendliness of small molecules, Scientific Reports 7 (2017) 42717. doi: 10.1038/srep42717. 
[50] A.Daina, V. Zoete, A BOILED-Egg to Predict Gastrointestinal Absorption and BrainPenetration of Small Molecules, ChemMedChem 11 (2016) 1117-1121. doi: 10.1002/cmdc.201600182.

[51] D. E.Pires, T. L.Blundell and D. B. Ascher, pkCSM: Predicting Small-Molecule Pharmacokinetic and Toxicity Properties Using Graph-Based Signatures, Journal of Medicinal Chemistry 58 (2015) 4066-4072. doi: 10.1021/acs.jmedchem.5b00104.

[52] F.Cheng, W.Li, Y.Zhou, J. Shen, Z. Wu, G.Liu, P. W. Lee andY.Tang, admetSAR: a comprehensive source and free tool for assessment of chemical ADMET properties, Journal of Chemical Information and Modeling 52 (2012) 3099-3105. doi: 10.1021/ci300367a.

[53] A. Daina, O. Michielinand V. Zoete, SwissTargetPrediction: updated data and new features for efficient prediction of protein targets of small molecules, Nucleic Acids Research 47 (2019) W357-W364. doi: 10.1093/nar/gkz382.

[54] V. Zoete, A. Daina, C. Bovigny and O.Michielin, SwissSimilarity: A Web Tool for Low to Ultra High Throughput Ligand-Based Virtual Screening, Journal of Chemical Information and Modeling 56 (2016) 1399-1404.doi: 10.1021/acs.jcim.6b00174.

[55] L.Dong, S. Hu, J. Gao, Discovering drugs to treat coronavirus disease 2019 (COVID-19),Drug Discoveries \& Therapeutics 14 (2020) 58-60. doi: 10.5582/ddt.2020.01012.

[56] S. G. V.Rosa, and W. C. Santos, Clinical trials on drug repositioning for COVID19 treatment, RevistaPanamericana de SaludPública 44 (2020) 1-13. doi.org/10.26633/RPSP.2020.40.

[57] T. Sekhar, Virtual Screening based prediction of potential drugs for COVID-19, Combinatorial Chemistry \& High Throughput Screening 23 (2020). doi: $10.2174 / 1386207323666200814132149$.

[58] M. W.Chang, C.Ayeni, S.BreuerandB. E. Torbett, Virtual screening for HIV protease inhibitors: a comparison of AutoDock 4 and Vina, PloS ONE 5 (2010) e11955. doi:10.1371/journal.pone.0011955. 
[59] V. Thiel, K. A.Ivanov, A.Putics, T. Hertzig,B. Schelle, S. Bayer, andA. E. Gorbalenya, Mechanisms and enzymes involved in SARS coronavirus genome expression, Journal of General Virology 84 (2003) 2305-2315. doi: 10.1099/vir.0.19424-0.

[60] J. F.Chan, S. K.Lau, K. K.To, V. C.Cheng, P. C. Woo and K. Y. Yuen, Middle East respiratory syndrome coronavirus: another zoonotic betacoronavirus causing SARS-like disease, Clinical Microbiology Reviews 28 (2015) 465-522. doi: 10.1128/CMR.0010214.

[61] J. P.MooreandR. W. Doms, The entry of entry inhibitors: a fusion of science and medicine. Proceedings of the National Academy of Sciences, Proceedings of the National Academy of Sciences of the United States of America 100 (2003) 10598-10602. doi: 10.1073/pnas.1932511100.

[62] M. A.Tortorici and D. Veesler, Structural insights into coronavirus entry, Advances In Virus Research 105 (2019) 93-116. doi: 10.1016/bs.aivir.2019.08.002.

[63] R. M. W.Hoetelmans, C. H. W.Koks,J. H.Beijnen, Meenhorst, P. L. Mulder, J. W. and D. M. Burger, Clinical pharmacology of HIV protease inhibitors: focus on saquinavir, indinavir, and ritonavir, Pharmacy World and Science 19 (1997) 159-175. doi: 10.1023/A:1008629608556.

[64] R. B. Diasio, Sorivudine and 5-fluorouracil; a clinically significant drug-drug interaction due to inhibition of dihydropyrimidine dehydrogenase, British Journal of Clinical Pharmacology 46 (1998) 1-4. doi: 10.1046/j.1365-2125.1998.00050.x.

[65] L. J. Pasquau and T. C. Hidalgo, Chemical characteristics, mechanism of action and antiviral activity of darunavir, EnfermedadesInfecciosas y MicrobiologiaClinica 26 (2008) 3-9. doi:10.1016/s0213-005x(08)76547-9.

[66] D. A.Davis, E. E.Soule, K. S.Davidoff, S. I.Daniels, N. E.Naiman and R. Yarchoan, Activity of human immunodeficiency virus type 1 protease inhibitors against the initial autocleavage in Gag-Pol polyprotein processing, Antimicrobial agents and Chemotherapy 56 (2012) 3620-3628. doi: 10.1128/AAC.00055-12.

[67] H. K.Shin, Y. M. Kang and K. T. No, Predicting ADME properties of chemicals, Handbook of Computational Chemistry (2017) 1-37. doi: 10.1007/978-94-007-61698_59-1 
[68] L. Guan, H. Yang, Y.Cai, L.Sun, P.Di, W.LiandY. Tang, ADMET-score-a comprehensive scoring function for evaluation of chemical drug-likeness, MedChemComm 10 (2019) 148-157. doi: 10.1039/C8MD00472B.

[69] A. G.Kieback, S. B.Felix and T. Reffelmann, Quinaprilat: a review of its pharmacokinetics, pharmacodynamics, toxicological data and clinical application, Expert Opinion on Drug Metabolism \& Toxicology 5 (2009) 1337-1347. doi: $10.1517 / 17425250903282773$.

[70] A. K.Seth, A.MisraandD.Umrigar, Topical liposomal gel of idoxuridine for the treatment of herpes simplex: pharmaceutical and clinical implications, Pharmaceutical Development and Technology 9 (2005) 277-289. doi: 10.1081/PDT-200031432.

[71] Y. Y.LuiandH. L. Chan, Treatment of chronic hepatitis B: focus on telbivudine, Expert Review of Anti-infective Therapy 7 (2009) 259-268. doi: 10.1586/eri.09.6.

[72] K. Y.Smith, W. G.Weinberg, E. DeJesus, M. A.Fischl, Q. Liao, L. L.RossandC. Lancaster, Fosamprenavir or atazanavir once daily boosted with ritonavir $100 \mathrm{mg}$, plus tenofovir/emtricitabine, for the initial treatment of HIV infection: 48-week results of ALERT, AIDS Research and Therapy 5 (2008) 5. doi: 10.1186/1742-6405-5-5.

[73] B. M.Sadler, C. D.Hanson, G. E.Chittick, W. T. Symonds and N. S. Roskell, Safety and pharmacokinetics of amprenavir (141W94), a human immunodeficiency virus (HIV) type 1 protease inhibitor, following oral administration of single doses to HIV-infected adults, Antimicrobial Agents and Chemotherapy 43 (1999) 1686-1692. doi: 10.1128/AAC.43.7.1686. 

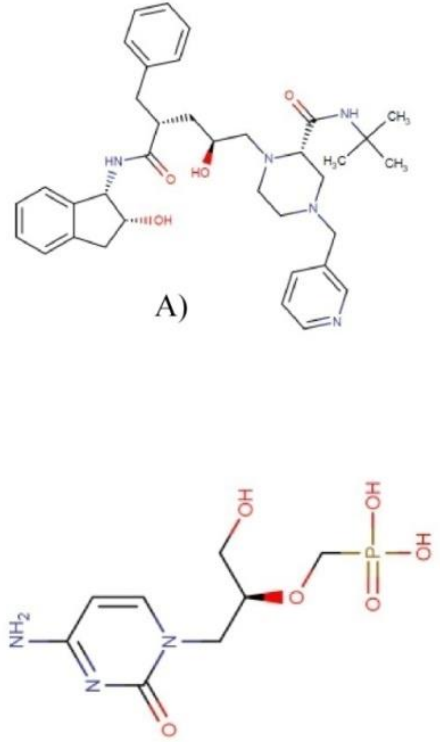

C)

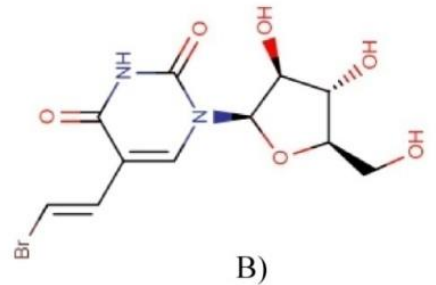

B)

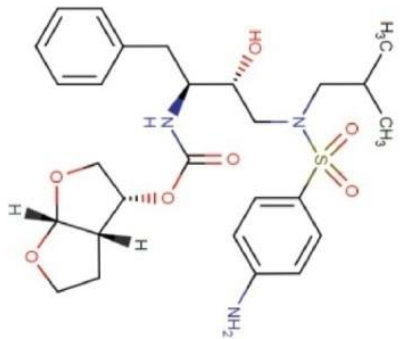

D)

Figure 1: Chemical structures of Indinavir (A), Sorivudine (B), Cidofovir (C) and Darunavir (D)

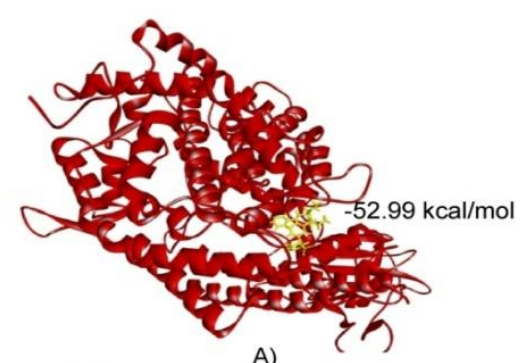

A)

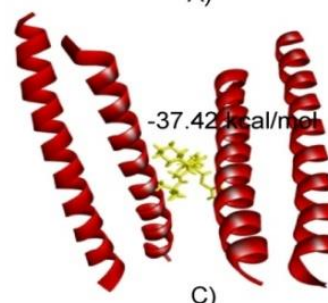

C)

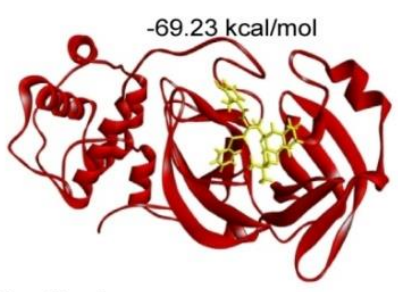

B)

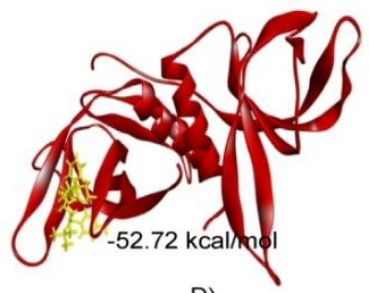

D)

Figure 2: Molecular interaction of Sorivudine with spike receptor-binding domain (A), Indinavir with main protease(B), Indinavir with HR2 Domain (C), Cidofovir with Nsp9 RNA binding protein (D) and (E) Darunavir with spike ectodomain. 


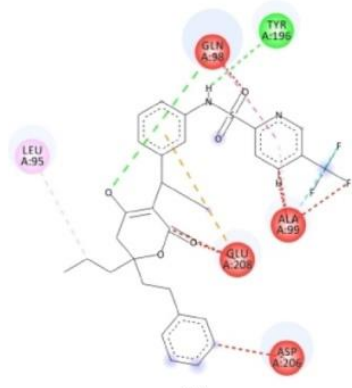

A)

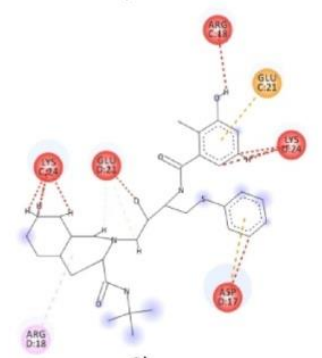

C)
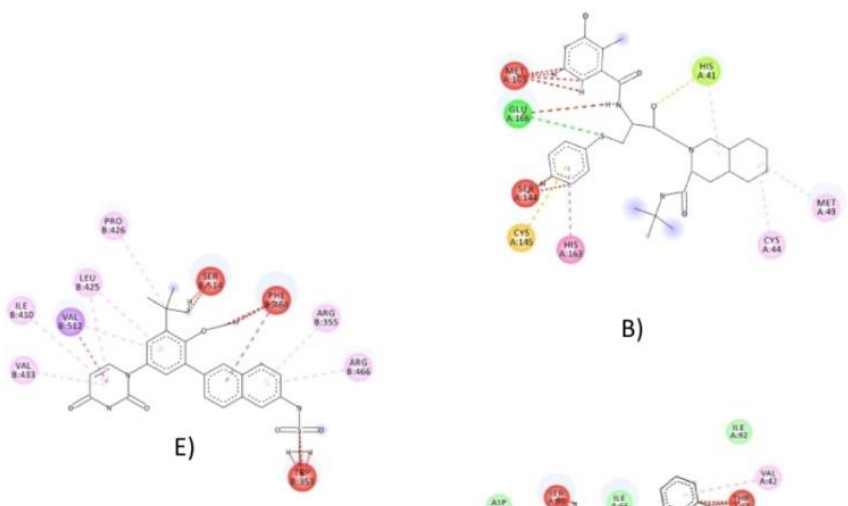

B)

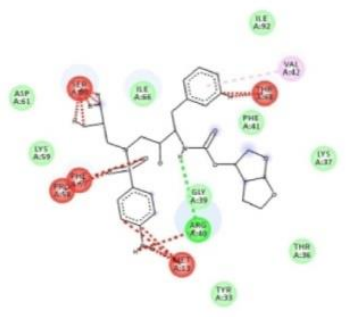

D)

Figure 3: Ligand binding site of Sorivudine with spike receptor-binding domain (A), Indinavir with main protease(B), Indinavir with HR2 Domain (C), Cidofovir with Nsp9 RNA binding protein (D) and (E) Darunavir with spike ectodomain.

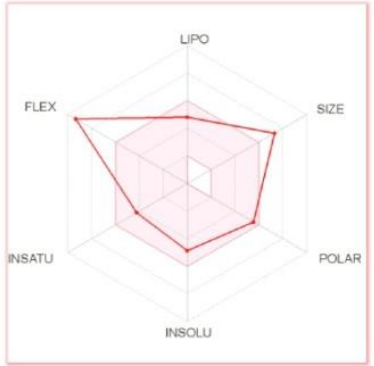

A)

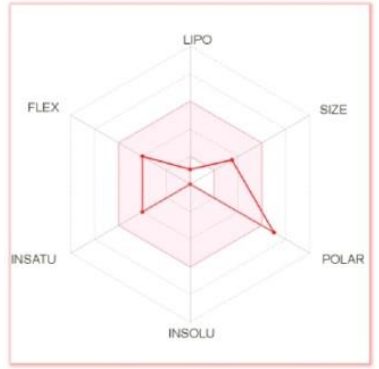

C)

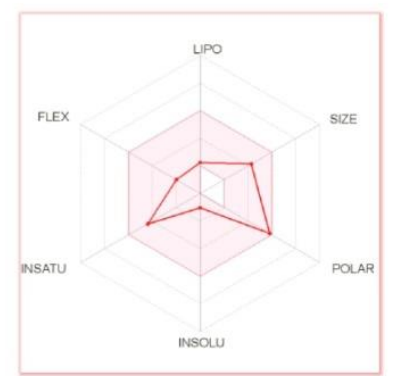

B)

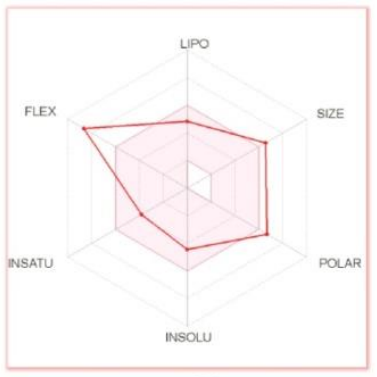

D)

Figure 4: ADME analysis of top four drugs; Indinavir (A), Sorivudine (B), Cidofovir (C) and Darunavir (D) 


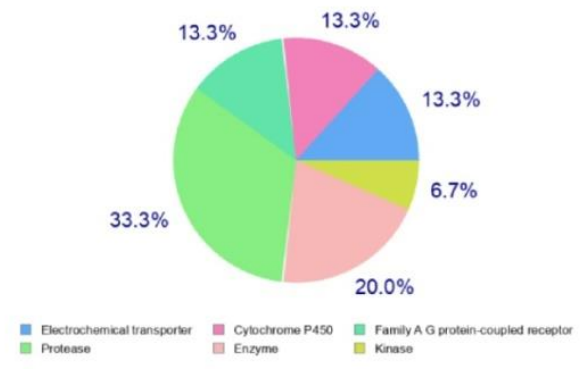

A)

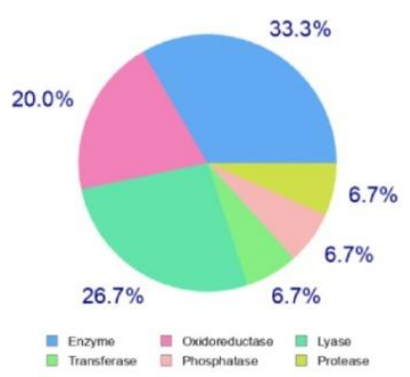

C)

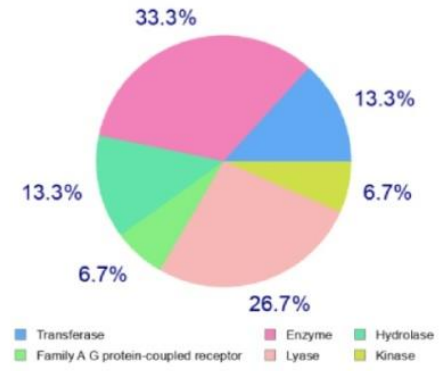

B)

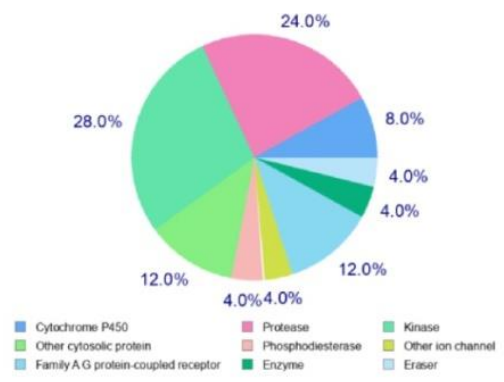

D)

Figure 5: Prediction of drug targets for Indinavir (A), Sorivudine (B), Cidofovir (C) and Darunavir (D)

Table 1: Analysis of binding energy of top four screened drugs (ligands)

\begin{tabular}{|c|c|c|c|c|c|c|}
\hline Macromolecules & Ligands & $\begin{array}{l}\text { Global } \\
\text { Energy }\end{array}$ & $\mathrm{ACE}$ & Score & Area & Binding sites \\
\hline \multirow{5}{*}{$\begin{array}{l}\text { HR2 } \\
(6 \mathrm{LVN})\end{array}$} & $\begin{array}{c}\alpha- \\
\text { ketoamide } \\
(\text { Control })\end{array}$ & -25.52 & -2.71 & 4318 & 564.20 & $\begin{array}{l}\text { Ile16, Asn20, Lys24, } \\
\text { Asn27, Glu28 }\end{array}$ \\
\hline & Indinavir & -37.42 & -2.33 & 5148 & 630.20 & $\begin{array}{c}\text { Gln13, Lys14, Ile16, } \\
\text { Asp17, Arg18, Asn20, } \\
\text { Glu21, Lys24 }\end{array}$ \\
\hline & Sorivudine & -29.12 & -1.81 & 4782 & 592.80 & $\begin{array}{c}\text { Gln13, Lys14, Asp17, } \\
\text { Arg18, Asn20, Glu21, } \\
\text { Lys24 }\end{array}$ \\
\hline & Cidofovir & -28.02 & -2.75 & 5082 & 568.60 & $\begin{array}{l}\text { Lys 14, Asp17, Arg18, } \\
\text { Asn20, Glu21, Lys24 }\end{array}$ \\
\hline & Darunavir & -26.27 & -0.43 & 5102 & 592.10 & $\begin{array}{c}\text { Lys14, Asp17, Arg18, } \\
\text { Asn20, Glu21, Ala23, } \\
\text { Lys24, Asn27 }\end{array}$ \\
\hline $\begin{array}{l}\text { Spike receptor } \\
\text { binding domain } \\
(6 \mathrm{M} 0 \mathrm{~J})\end{array}$ & $\begin{array}{l}\alpha- \\
\text { ketoamide } \\
(\text { Control })\end{array}$ & -60.50 & -9.34 & 5374 & 655.40 & $\begin{array}{c}\text { Lys94, Tyr196, Asp206, } \\
\text { Glu208, Val209, } \\
\text { Asn210 }\end{array}$ \\
\hline
\end{tabular}




\begin{tabular}{|c|c|c|c|c|c|c|}
\hline & & & & & & \\
\hline & Indinavir & -49.51 & -13.44 & 6372 & 765.30 & $\begin{array}{l}\text { Leu95, Leu97, Gln98, } \\
\text { Ala99, Gln101, Tyr196, } \\
\text { Tyr202, Trp203, } \\
\text { Gly205, Asp206, } \\
\text { Glu208, Val209, } \\
\text { Asn210, Ala396, } \\
\text { Lys562, Glu564, } \\
\text { Pro565, Trp566 }\end{array}$ \\
\hline & Sorivudine & -52.99 & -10.46 & 6254 & 787.40 & $\begin{array}{l}\text { Leu95, Gln98, Ala99, } \\
\text { Gln102, Tyr196, } \\
\text { Gly205, Asp206, } \\
\text { Glu208, Val209, } \\
\text { Asn210, Ala396, } \\
\text { Glu398, Lys562, } \\
\text { Glu564, Pro565, Trp566 }\end{array}$ \\
\hline & Cidofovir & -49.19 & -13.26 & 6206 & 795.80 & $\begin{array}{c}\text { Lys94, Leu95, Gln98, } \\
\text { Ala99, Gln102, Tyr196, } \\
\text { Tyr202, Gly205, } \\
\text { Asp206, Tyr207, } \\
\text { Glu208, Val209, } \\
\text { Asn210, Ala396, } \\
\text { Lys562, Glu564, } \\
\text { Pro565, Trp566 }\end{array}$ \\
\hline & Darunavir & -46.88 & -14.07 & 5456 & 667.50 & $\begin{array}{c}\text { Leu95, Gln102, Asn103, } \\
\text { Asn194, Tyr196, } \\
\text { Tyr202, Trp203, } \\
\text { Gly205, Asp206, } \\
\text { Tyr207, Glu208, } \\
\text { Val209, Ala396, } \\
\text { Lys562, Glu564, } \\
\text { Pro565, Trp566 }\end{array}$ \\
\hline & $\begin{array}{l}\alpha- \\
\text { ketoamide } \\
\text { (Control) }\end{array}$ & -63.94 & -17.32 & 5728 & 705.10 & $\begin{array}{c}\text { Thr547, Gly548, } \\
\text { Thr549,Asp745, Val976 }\end{array}$ \\
\hline $\begin{array}{l}\text { Spike ecto-domain } \\
\text { (6VYB) }\end{array}$ & Indinavir & -37.29 & -4.09 & 7150 & 854.60 & $\begin{array}{c}\text { Arg765, Ala766, } \\
\text { Thr768, Gly769, Ile770, } \\
\text { Val772, Glu773, } \\
\text { Lys776, Glu780, } \\
\text { Lys947, Asp950, } \\
\text { Gln954, Gln957, } \\
\text { Gln1010, Leu1012, } \\
\text { Ile1013, Arg1014, } \\
\text { Glu1017, Arg1019 }\end{array}$ \\
\hline & Sorivudine & -52.28 & -14.36 & 6848 & 824.30 & Arg319, Phe541, \\
\hline
\end{tabular}




\begin{tabular}{|c|c|c|c|c|c|c|}
\hline & & & & & & $\begin{array}{c}\text { Thr547, Gly548, } \\
\text { Thr549, Asp571, } \\
\text { Thr572, Thr573, } \\
\text { Pro589, Cys590, } \\
\text { Phe593, Met740, } \\
\text { Cys743, Gly744, } \\
\text { Asp745, Ser746, } \\
\text { Asn856, Leu966, } \\
\text { Ser975, Val976, } \\
\text { Leu977, Asn978, } \\
\text { Arg1000 }\end{array}$ \\
\hline & Cidofovir & -42.21 & -9.27 & 6714 & 774.20 & $\begin{array}{l}\text { Leu368, Tyr369, } \\
\text { Asn370, Ser371, } \\
\text { Ala372, Ser373, } \\
\text { Phe374, Ser375, } \\
\text { Thr376, Phe377, } \\
\text { Arg403, Asp405, } \\
\text { Glu406, Arg408, } \\
\text { Gln409, Thr415, } \\
\text { Gly416, Lys417, } \\
\text { Asn437, Tyr453 }\end{array}$ \\
\hline & Darunavir & -68.01 & -25.44 & 6174 & 845.70 & $\begin{array}{c}\text { Ser349, Val350, } \\
\text { Tyr351, Ala352, } \\
\text { Trp353, Asn354, } \\
\text { Arg355, Asp398, } \\
\text { Ile410, Ala411, Asn422, } \\
\text { Tyr423, Lys424, } \\
\text { Leu425, Pro426, } \\
\text { Phe429, Thr430, } \\
\text { Gly431, Cys432, } \\
\text { Val433, Pro463, } \\
\text { Phe464, Arg466, } \\
\text { Val512, Ser514, Phe515 }\end{array}$ \\
\hline \multirow{3}{*}{$\begin{array}{l}\text { Nsp9 } \\
\text { binding } \\
\text { protein }(6 \mathrm{~W} 4 \mathrm{~B})\end{array}$} & $\begin{array}{l}\alpha- \\
\text { ketoamide } \\
\text { (Control) }\end{array}$ & -48.60 & -16.39 & 4458 & 504.60 & $\begin{array}{c}\text { Phe41, Trp54, Ile66, } \\
\text { Thr68, Glu69 }\end{array}$ \\
\hline & Indinavir & -43.27 & -13.58 & 5908 & 755.00 & $\begin{array}{c}\text { Met13, Ser14, Thr36, } \\
\text { Lys37, Gly38, Gly39, } \\
\text { Arg40, Phe41, Val42, } \\
\text { Phe57, Pro58, Lys59, } \\
\text { Ser60, Asp61, Ile66, } \\
\text { Thr68 }\end{array}$ \\
\hline & Sorivudine & -25.09 & -10.17 & 5506 & 643.50 & $\begin{array}{l}\text { Met13, Gly38, Gly39, } \\
\text { Arg40, Phe41, Val42, } \\
\text { Phe57, Pro58, Lys59, } \\
\text { Ser60, Asp61, Thr63, }\end{array}$ \\
\hline
\end{tabular}




\begin{tabular}{|c|c|c|c|c|c|c|}
\hline & & & & & & Ile66 \\
\hline & Cidofovir & -52.74 & -18.32 & 5456 & 683.20 & $\begin{array}{l}\text { Met13, Tyr33, Gly39, } \\
\text { Arg40, Phe41, Val42, } \\
\text { Phe57, Pro58, Lys59, } \\
\text { Ser60, Asp61, Ile66, } \\
\text { Thr68 }\end{array}$ \\
\hline & Darunavir & -47.62 & -17.90 & 5350 & 640.90 & $\begin{array}{l}\text { Met13, Ser14, Gly39, } \\
\text { Arg40, Phe41, Val42, } \\
\text { Phe57, Pro58, Lys59, } \\
\text { Ser60, Asp61, Ile66, } \\
\text { Thr68 }\end{array}$ \\
\hline \multirow{4}{*}{$\begin{array}{l}\text { Main protease } \\
\text { (6W63) }\end{array}$} & $\begin{array}{l}\alpha- \\
\text { ketoamide } \\
\text { (Control) }\end{array}$ & -56.92 & -16.84 & 4560 & 526.40 & $\begin{array}{l}\text { Asp197, Leu272, } \\
\text { Gly275, Leu286, } \\
\text { Leu287, Asp289 }\end{array}$ \\
\hline & Indinavir & -69.23 & -21.97 & 5584 & 695.70 & $\begin{array}{l}\text { Thr25, Leu27, His41, } \\
\text { Val42, Cys44, Thr45, } \\
\text { Ser46, Met49, Phe140, } \\
\text { Leu141, Asn142, } \\
\text { Gly143, Ser144, } \\
\text { Cys145, His163, } \\
\text { His164, Met165, } \\
\text { Glu166, Leu167, } \\
\text { Pro168, His172, } \\
\text { Val186, Asp187, } \\
\text { Arg188, Gln189, } \\
\text { Gln192 }\end{array}$ \\
\hline & Sorivudine & -59.62 & -19.53 & 5816 & 704.90 & $\begin{array}{c}\text { Thr25, Leu27, His41, } \\
\text { Cys44, Thr45, Ser46, } \\
\text { Met49, Tyr54, Phe140, } \\
\text { Leu141, Asn142, } \\
\text { Gly143, Ser144, } \\
\text { Cys145, His163, } \\
\text { His164, Met165, } \\
\text { Glu166, Leu167, } \\
\text { Pro168, His172, } \\
\text { Asp187, Arg188, } \\
\text { Gln189, }\end{array}$ \\
\hline & Cidofovir & -56.49 & -18.88 & 6074 & 720.90 & $\begin{array}{l}\text { Thr24, Thr25, Thr26, } \\
\text { Leu27, His41, Val42, } \\
\text { Cys44, Ser46, Met49, } \\
\text { Phe140, Leu141, } \\
\text { Asn142, Gly143, } \\
\text { Ser144, Cys145, } \\
\text { His163, His164, } \\
\text { Met165, Glu166, } \\
\text { His172, Val186, }\end{array}$ \\
\hline
\end{tabular}




\begin{tabular}{|c|c|c|c|c|c|c|}
\hline \multirow[b]{2}{*}{ 列 } & & & & & & $\begin{array}{r}\text { Asp187, Arg188, } \\
\text { Gln189, Gln192 }\end{array}$ \\
\hline & Darunavir & -55.06 & -19.64 & 5240 & 670.40 & $\begin{array}{c}\text { Thr25, Leu27, His41, } \\
\text { Val42, Cys44, Thr45, } \\
\text { Ser46, Met49, Phe140, } \\
\text { Leu141, Asn142, } \\
\text { Ser144, Cys145, } \\
\text { His163, His164, } \\
\text { Met165, Glu166, } \\
\text { His 172, Val186, } \\
\text { Asp187, Arg188, } \\
\text { Gln189, Thr190 }\end{array}$ \\
\hline
\end{tabular}

Table 2: Drug profile and ADME analysis of top four drugs

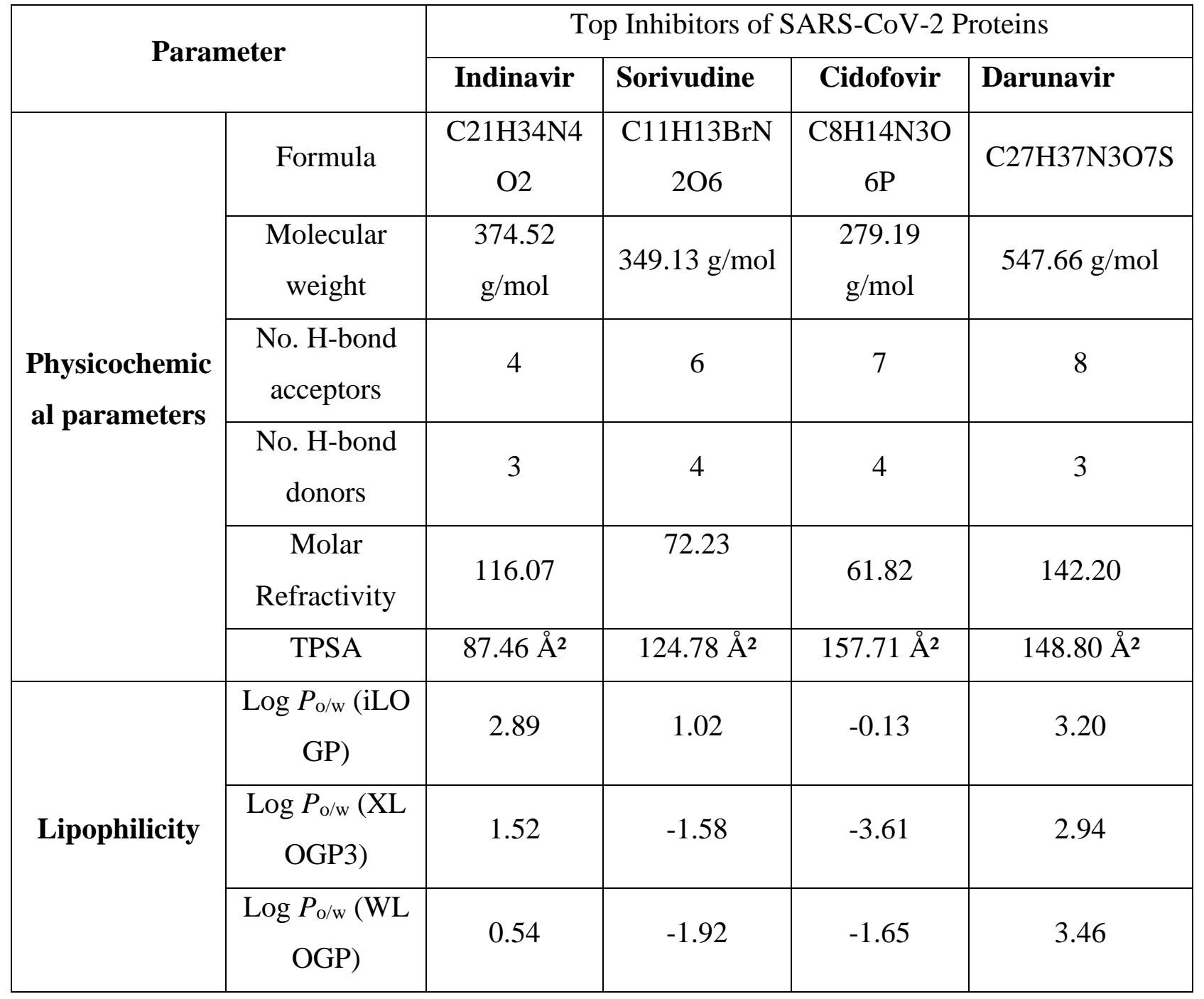




\begin{tabular}{|c|c|c|c|c|c|}
\hline & $\begin{array}{c}\log P_{\mathrm{o} / \mathrm{w}}(\mathrm{ML} \\
\text { OGP })\end{array}$ & 1.21 & -0.90 & -2.25 & 1.18 \\
\hline & $\begin{array}{c}\log P_{\mathrm{o} / \mathrm{w}}(\mathrm{SIL} \\
\text { ICOS-IT) }\end{array}$ & 2.42 & -0.19 & -2.41 & 1.46 \\
\hline & $\begin{array}{l}\text { Consensus } \\
\log P_{\mathrm{o} / \mathrm{w}}\end{array}$ & 1.71 & -0.71 & -2.01 & 2.45 \\
\hline & GI absorption & High & Low & Low & Low \\
\hline & $\begin{array}{c}\text { BBB } \\
\text { permeant }\end{array}$ & No & No & No & No \\
\hline & P-gp substrate & Yes & No & No & Yes \\
\hline & $\begin{array}{l}\text { CYP1A2 } \\
\text { inhibitor }\end{array}$ & No & No & No & No \\
\hline Pharmacokine & $\begin{array}{l}\text { CYP2C19 } \\
\text { inhibitor }\end{array}$ & No & No & No & No \\
\hline tics & $\begin{array}{l}\text { CYP2C9 } \\
\text { inhibitor }\end{array}$ & No & No & No & No \\
\hline & $\begin{array}{l}\text { CYP2D6 } \\
\text { inhibitor }\end{array}$ & Yes & No & No & No \\
\hline & $\begin{array}{l}\text { CYP3A4 } \\
\text { inhibitor }\end{array}$ & No & No & No & Yes \\
\hline & $\begin{array}{l}\log K_{\mathrm{p}} \text { (skin } \\
\text { permeation) }\end{array}$ & $-7.51 \mathrm{~cm} / \mathrm{s}$ & $-9.55 \mathrm{~cm} / \mathrm{s}$ & $-10.57 \mathrm{~cm} / \mathrm{s}$ & $-7.55 \mathrm{~cm} / \mathrm{s}$ \\
\hline & $\log S(\mathrm{ESOL})$ & -2.62 & -1.03 & 0.85 & -4.46 \\
\hline $\begin{array}{c}\text { Water } \\
\text { Solubility }\end{array}$ & Solubility & $\begin{array}{c}8.90 \mathrm{e}-01 \\
\mathrm{mg} / \mathrm{ml} \\
2.38 \mathrm{e}-03 \\
\mathrm{~mol} / \mathrm{l}\end{array}$ & $\begin{array}{c}3.23 \mathrm{e}+01 \\
\mathrm{mg} / \mathrm{ml} \\
9.26 \mathrm{e}-02 \\
\mathrm{~mol} / \mathrm{l}\end{array}$ & $\begin{array}{c}1.99 \mathrm{e}+03 \\
\mathrm{mg} / \mathrm{ml} \\
7.12 \mathrm{e}+00 \\
\mathrm{~mol} / \mathrm{l}\end{array}$ & $\begin{array}{l}1.88 \mathrm{e}-02 \mathrm{mg} / \mathrm{ml} \\
; 3.44 \mathrm{e}-05 \mathrm{~mol} / \mathrm{l}\end{array}$ \\
\hline & Class & Soluble & Very soluble & $\begin{array}{l}\text { Highly } \\
\text { soluble }\end{array}$ & $\begin{array}{c}\text { Moderately } \\
\text { soluble }\end{array}$ \\
\hline & $\log S($ SILIC & -5.08 & -0.15 & 0.33 & -5.33 \\
\hline
\end{tabular}




\begin{tabular}{|c|c|c|c|c|c|}
\hline & OS-IT) & & & & \\
\hline & Solubility & $\begin{array}{c}3.15 \mathrm{e}-03 \\
\mathrm{mg} / \mathrm{ml} \\
8.41 \mathrm{e}-06 \\
\mathrm{~mol} / \mathrm{l}\end{array}$ & $\begin{array}{c}2.45 \mathrm{e}+02 \\
\mathrm{mg} / \mathrm{ml} ; \\
7.03 \mathrm{e}-01 \\
\mathrm{~mol} / \mathrm{l}\end{array}$ & $\begin{array}{c}5.97 \mathrm{e}+02 \\
\mathrm{mg} / \mathrm{ml} ; \\
2.14 \mathrm{e}+00 \\
\mathrm{~mol} / \mathrm{l}\end{array}$ & $\begin{array}{l}2.55 \mathrm{e}-03 \mathrm{mg} / \mathrm{ml} \\
; 4.66 \mathrm{e}-06 \mathrm{~mol} / \mathrm{l}\end{array}$ \\
\hline & Class & $\begin{array}{c}\text { Moderately } \\
\text { soluble }\end{array}$ & Soluble & Soluble & $\begin{array}{c}\text { Moderately } \\
\text { soluble }\end{array}$ \\
\hline \multirow{4}{*}{$\begin{array}{l}\text { Medicinal } \\
\text { Chemistry }\end{array}$} & Leadlikeness & $\begin{array}{c}\text { No; } 2 \\
\text { violations: } \\
\text { MW>350, } \\
\text { Rotors }>7\end{array}$ & Yes & Yes & $\begin{array}{c}\text { No; } 2 \\
\text { violations: } \\
\text { MW>350, } \\
\text { Rotors }>7\end{array}$ \\
\hline & $\begin{array}{c}\text { Bioavailabilit } \\
\text { y Score }\end{array}$ & 0.55 & 0.55 & 0.11 & 0.55 \\
\hline & PAINS & 0 alert & 0 alert & 0 alert & 0 alert \\
\hline & $\begin{array}{l}\text { Synthetic } \\
\text { accessibility }\end{array}$ & 3.53 & 4.23 & 3.41 & 5.67 \\
\hline
\end{tabular}


Table 3: Toxicity patterns of top four drugs

\begin{tabular}{|l|l|l|l|l|}
\hline \multirow{2}{*}{ Toxicity Parameter } & \multicolumn{3}{|c|}{ Drug Name } \\
\cline { 2 - 5 } & Indinavir & Sorivudine & Cidofovir & Darunavir \\
\hline AMES Test & No & No & No & No \\
\hline Max. Tolerated Dose (log mg/kg/day) & -0.358 & 1.274 & 0.187 & -0.763 \\
\hline hERG I inhibitor & No & No & No & No \\
\hline hERG II inhibitors Acute Toxicity, LD50 & 2.914 & 2.172 & 1.74 & No \\
\hline $\begin{array}{l}\text { Oral Rat } \\
\text { (mol/kg) }\end{array}$ & & & & 2.107 \\
\hline $\begin{array}{l}\text { Oral Rat Chronic Toxicity,LOAEL } \\
\text { (log mg/kg_bw/day) }\end{array}$ & 1.428 & 3.004 & 3.131 & 2.775 \\
\hline Hepatotoxicity & & & & \\
\hline $\begin{array}{l}\text { Carcinogen } \\
\text { Yes }\end{array}$ & Non & Non & Yes & Yes \\
\hline Skin Sensitisation & carcinogen & carcinogen & carcinogen & carcinogen \\
\hline T. pyriformis Toxicity $(\log \mu \mathrm{g} / \mathrm{L})$ & 0.285 & 0.285 & 0.284 & No \\
\hline \begin{tabular}{l} 
Minnow Toxicity (log mM) \\
\hline
\end{tabular} & 5.061 & 4.043 & 4.381 & 0.61 \\
\hline
\end{tabular}

Table 4: Predicted drug targets for Indinavir, Sorivudine, Cidofovir and Darunavir

\begin{tabular}{|c|c|c|c|c|c|c|}
\hline Drugs & $\begin{array}{c}\text { Drug } \\
\text { Targets }\end{array}$ & $\begin{array}{c}\text { Common } \\
\text { Name }\end{array}$ & $\begin{array}{c}\text { Uniprot } \\
\text { ID }\end{array}$ & ChEMBL ID & Target Class & Probability* \\
\hline & $\begin{array}{l}\text { Multidrug } \\
\text { and toxin } \\
\text { extrusion } \\
\text { protein } 1\end{array}$ & SLC47A1 & Q96FL8 & CHEMBL1743126 & $\begin{array}{c}\text { Electrochemical } \\
\text { transporter }\end{array}$ & \\
\hline Indinavir & $\begin{array}{l}\text { Multidrug } \\
\text { and toxin } \\
\text { extrusion }\end{array}$ & SLC47A2 & Q86VL8 & CHEMBL1743127 & $\begin{array}{c}\text { Electrochemical } \\
\text { transporter }\end{array}$ & \\
\hline
\end{tabular}




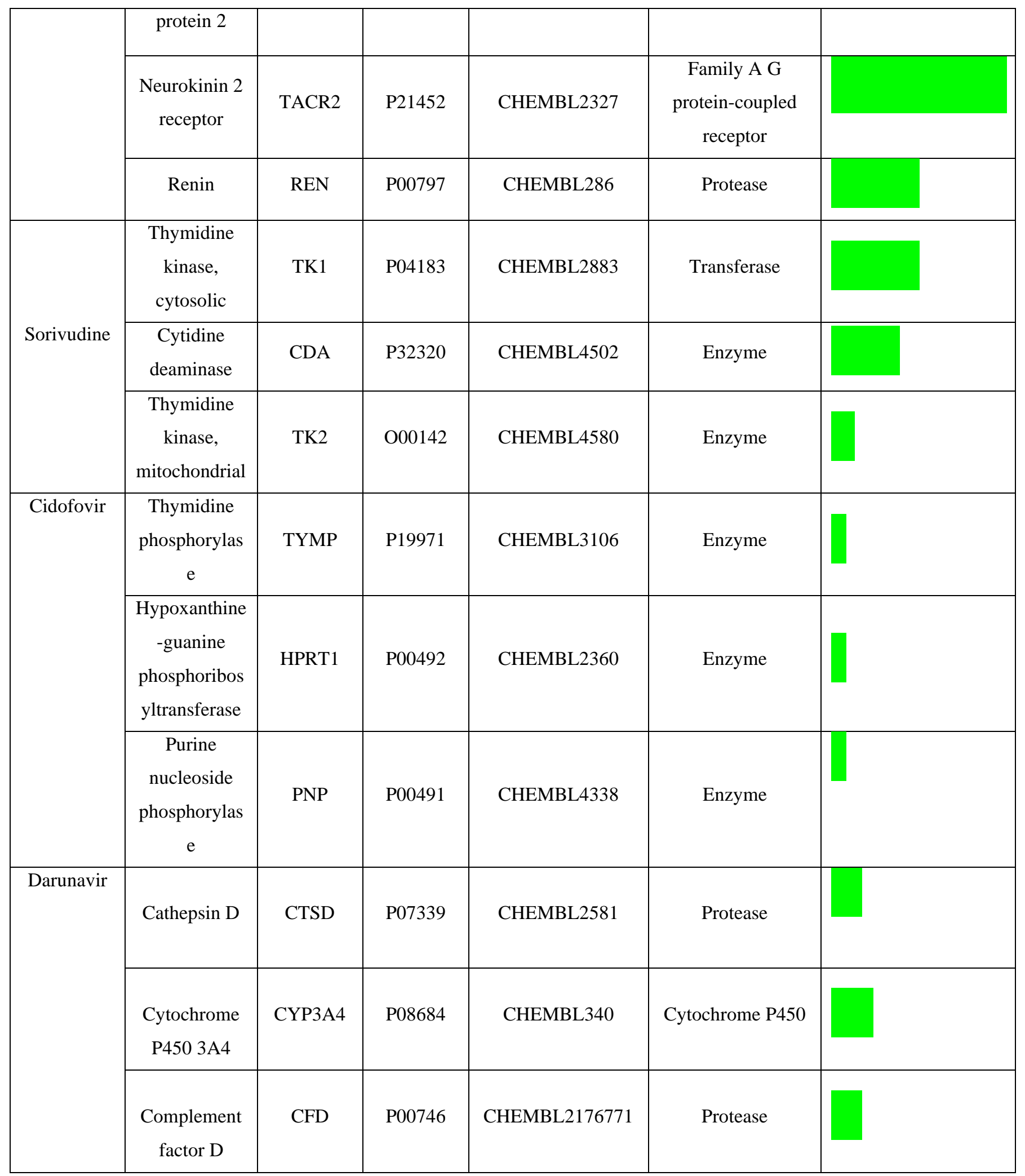


Table 5: Structural similar bioactive molecules from drug bank

\begin{tabular}{|c|c|c|c|l|}
\hline \multirow{3}{*}{ Drugs } & $\begin{array}{c}\text { Similar structure Drug } \\
\text { bank id }\end{array}$ & Name & Score & \multicolumn{1}{|c|}{ Status } \\
\hline \multirow{3}{*}{ Indinavir } & Quinapril & DB00881 & 0.048 & Approved \\
\cline { 2 - 5 } & Sirolimus & DB00877 & 0.014 & Approved \\
\cline { 2 - 5 } & L-756,423 & DB02009 & 0.906 & Experimental \\
\hline \multirow{3}{*}{ Sorivudin } & Telbivudine & DB01265 & 0.933 & Approved \\
\cline { 2 - 5 } & Idoxuridine & DB00249 & 0.863 & Approved \\
\hline \multirow{2}{*}{ Cidofovir } & Tenofovir & DB00300 & 0.811 & Approved \\
\cline { 2 - 5 } & Riboflavin & DB00140 & 0.127 & Approved \\
\hline \multirow{2}{*}{ Darunavir } & Amprenavir & DB00701 & 0.983 & Approved \\
\cline { 2 - 5 } & Fosamprenavir & DB01319 & 0.503 & Approved \\
\hline
\end{tabular}




\section{Graphical Abstract :}

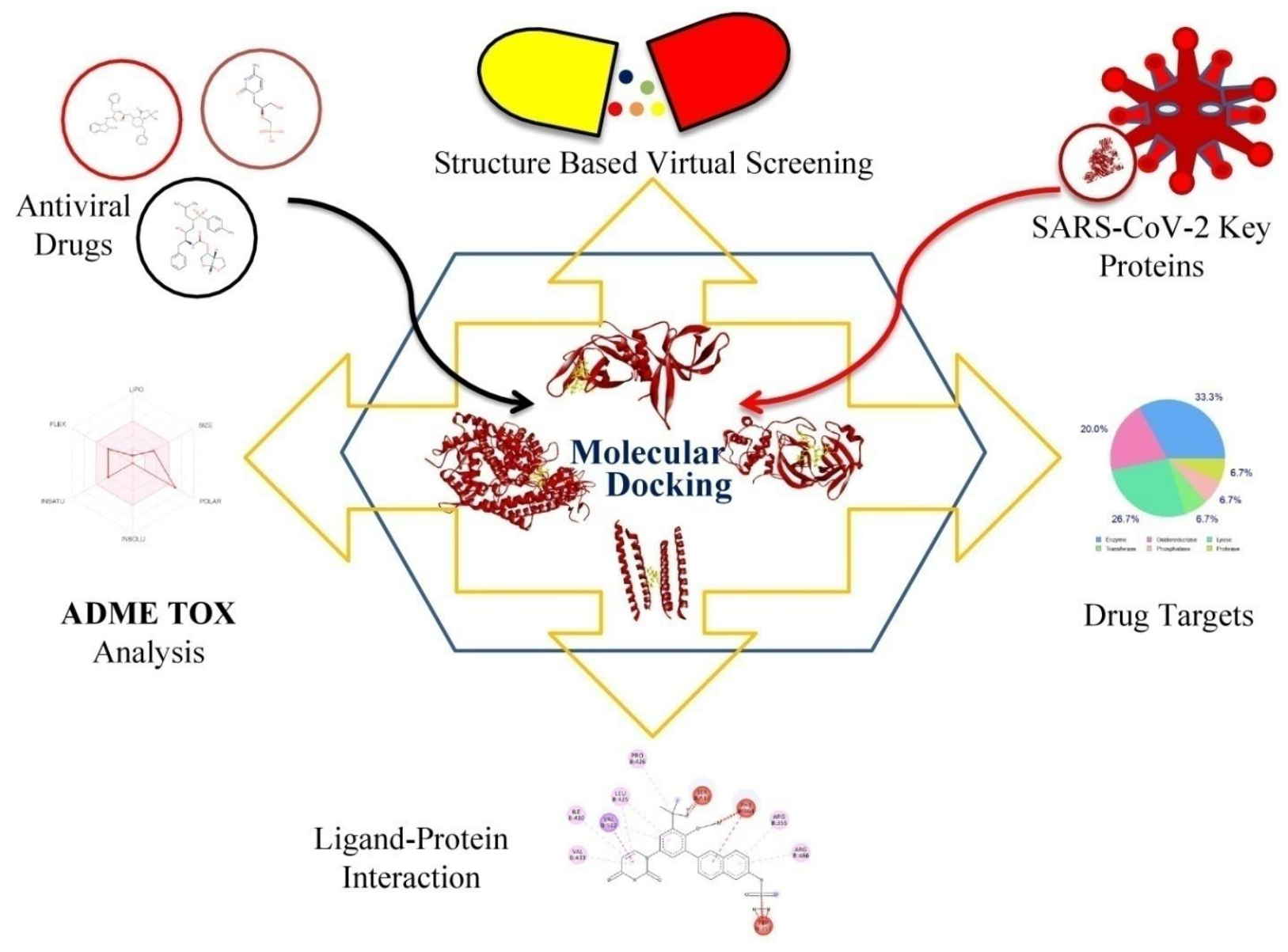

